\title{
New York City's Congestion Pricing Experience and Implications for Road Pricing Acceptance in the United States
}

\author{
Bruce Schaller $^{1}$ \\ Deputy Commissioner for Planning and Sustainability \\ New York City Department of Transportation \\ 55 Water Street, $9^{\text {th }}$ floor \\ New York, NY 10041 USA \\ bschaller@dot.nyc.gov
}

Published in Transport Policy, August 2010.

Citation: Transport Policy 17 (2010) 266-273

${ }^{1}$ Opinions expressed in this paper are the responsibility of the author and do not necessarily represent those of the NYCDOT or the City of New York. 


\begin{abstract}
Public acceptance is widely recognized as a major barrier to widespread adoption of road pricing in the United States and internationally. Using New York City as a case study, this paper analyzes how Mayor Michael Bloomberg's 2007 congestion pricing proposal gained widespread public support but was ultimately blocked in the State Legislature. The paper assesses the implications of New York's experience for pursuing congestion pricing and mileage-based taxes in the United States. A central conclusion from this analysis is that gaining approval of pricing will require changing how motorists view the effect of pricing on them personally. Given the power of even small groups of auto users to block pricing through the political process, pricing proposals need to be perceived as benefiting drivers individually and not simply society at large. The paper discusses approaches to road pricing in light of New York City’s experience.
\end{abstract}

Keywords: road pricing, congestion pricing, mileage-based pricing; public acceptance, New York City

\title{
1. INTRODUCTION
}

New York City's congestion pricing proposal was the first areawide road pricing scheme proposed for a major North American city. Under the proposal, New York would have joined Singapore, London and Stockholm as the fourth large city that charges for driving into the central city core.

Introduced in April 2007 as part of New York City Mayor Michael Bloomberg's comprehensive sustainability plan, the proposal was subject to intensive citywide debate and discussion over the subsequent 12 months. By the end of this period, both proponents and opponents of congestion pricing agreed on the importance of achieving the goals of congestion reduction, cleaner air and increased funding for mass transit improvements. Polls showed that New York City residents backed the proposal by a 67\% to 27\% margin provided that the money was used for expanded transit service (Quinnipiac University, 2008). A majority of City Council members voted to support a modified pricing proposal put forth by a State Commission, and the State Senate was poised to do likewise. Nevertheless, inaction by the New York State Assembly meant that the Legislature did not adopt authorizing legislation by an April 2008 federal funding deadline. An attempt to revive road pricing a year later in the form of bridge tolls also failed to win Legislative support, although the positions of the two houses were reversed.

This paper traces the origins of Mayor Bloomberg's congestion pricing proposal, the contours of the debate and the legislative outcome for both congestion pricing and bridge tolls. Based on the author's research on public acceptance of congestion pricing in New York City (Schaller, 2006) and first-hand observations during the course of the events, the paper focuses on how the central arguments in the public debate affected public acceptance and the ultimate outcome in Albany. The paper then assesses the implications of the New York City experience for public acceptance and adoption of road pricing nationally, including both congestion pricing and mileage-based fees, which are widely seen as the long-term future of transportation finance.

A central conclusion from this analysis is that gaining broad public acceptance and approval of congestion pricing or mileage-based fees will require changing how motorists see pricing as affecting their own best interests. Given the ability of auto users to thwart pricing 
through the political process, pricing programs need to be formulated such that drivers see fees or tolls as benefitting individual drivers.

\section{ORIGINS OF THE CONGESTION PRICING PROPOSAL}

The origins of Mayor Bloomberg's proposal for charging vehicles that travel in the core of Manhattan are critical to understanding how the debate over congestion pricing took shape. The April 2007 proposal was the product of several largely separate developments occurring within and outside City government. These developments came together in late 2006 and early 2007 and led the Mayor to decide to propose a pricing scheme, which attracted widespread support from groups throughout the city.

Discussion of congestion pricing first arose among civic and advocacy groups that had long been focused on the city's transportation needs. These groups included a regional planning association and groups that advocate for transit riders, pedestrians and bicyclists. The planning and advocacy groups had campaigned for the massive capital investments in the region's dilapidated mass transit system in the 1980s that led to the revival of the transit system. Inspired by London's successful implementation of congestion pricing in February 2003, these groups came to see congestion pricing as a way to reduce congestion, expand bus service, increase walking and cycling and generate funds for mass transit.

These transportation-oriented planning and advocacy groups were joined by business and environmental groups concerned about the economic and environmental effects of congested streets and highways. The Partnership for New York City, representing large businesses in the city, became a key proponent of congestion pricing. Environmental and labor groups which had not historically made transportation a central focus of their efforts joined the burgeoning coalition of civic and business organizations in support of congestion pricing policies as well. This loosely-knit coalition was also joined by university-based research centers and several elected officials.

These organizations - and some elected officials - held public forums and issued a series of reports that examined the role of auto use in the city and the economic and health costs of traffic congestion. These reports put a \$13 billion price tag on the regional cost of congestion (Partnership for New York City, 2006), argued that driving into Manhattan was not a "necessity" for most auto users (Schaller Consulting, 2006), analyzed alternative pricing schemes and discussed the technical feasibility of congestion pricing (Zupan and Perrotta, 2003), showed the existence of a strong voter desire to redress the impacts of traffic congestion (Michaels Opinion Research, 2006), and identified the barriers to gaining public acceptance (Schaller, 2006). At a time when it was far from clear that congestion pricing would ever gain life as a serious proposal for New York City, these studies and discussions helped lay the foundation for the City's development of the Mayor's proposal. They also helped prepare pricing proponents for the intense public discussion that followed.

A second important development was the newly re-elected Mayor's decision in early 2006 to develop a long-term land use plan for the city. This decision grew out of the city's continuing population and job growth coupled with the city government's growing difficulty in finding properties suitable for facilities as diverse as new schools and trash transfer stations. Developed by a new Mayor's Office of Long-Term Planning and Sustainability under the city's Deputy Mayor for Economic Development, the plan was expanded to encompass water, air, energy and transportation. With an increasing national focus on climate change in 2006, the plan was framed as a 25-year sustainability plan to create a "greener, greater New York." 
The year leading up to release of PlaNYC thus saw increased discussion of the transportation needs of the city and the expanded involvement of business and environmental groups and City Hall in transportation issues. This period also saw growing public concern with the impacts of population and job growth on the city's transportation system, air quality and climate change.

Mayor Bloomberg released PlaNYC on Earth Day in April 2007 at a marquee event at the Museum of Natural History, attended by several hundred civic leaders and city officials. PlaNYC included 127 initiatives designed to make New York City's air the cleanest of any major U.S. city, reduce greenhouse gas emissions by 30\% by 2030, and achieve a state of good repair for the city's streets and mass transit system, among other goals (City of New York, 2007).

By far the most attention was focused on the Mayor's proposal to charge an \$8 daily fee to cars traveling in the Manhattan core (including the Midtown and lower Manhattan central business districts) on weekdays between 6 a.m. and 6 p.m. Under the Mayor's plan, congestion fees could be paid using the established E-ZPass electronic tolling system, or through cash and credit card payment channels at retail stores, telephone and web-based systems. Tolls paid on bridges and tunnels in the city would offset the congestion fees so that congestion fees would not cause any driver to pay more than $\$ 8$ in fees and tolls to drive in the pricing zone. The net proceeds of congestion fees would be devoted to transportation improvements through a \$31 billion regional SMART Financing Authority. (See Figure 1 and Table 1.)

While congestion pricing generated strong feelings both in favor and against, overall press and public reaction was surprisingly positive. The proposal benefitted profoundly from being part of an ambitious and wide-ranging sustainability plan whose fundamental goals and values were environmental stewardship, urban vitality and enhanced quality of life. Announced at a time of growth and prosperity, PlaNYC was seen as a bold plan to address fundamental and intertwined issues upon which the future of the city rested.

\section{BATTLE OVER ADOPTION, MAY 2007 TO APRIL 2008}

Bloomberg's proposal was introduced in the State Legislature in June 2007, but the Legislature adjourned its regular session without taking action. In mid-July, under pressure from City Hall, newspaper editorial boards and civic and other groups, the Legislature reconvened and created a 17-member Traffic Congestion Mitigation Commission.

The Commission's members were appointed by every entity that would act on its recommendations: the Governor, Mayor, heads of the majority and minority conferences in each house of the Legislature, and the City Council speaker. The Commission was charged with evaluating different approaches to traffic congestion in the central part of Manhattan, including both pricing and non-pricing approaches, and making a recommendation to the Legislature by January 31, 2008.

During the spring and summer of 2007, the City and the Metropolitan Transportation Authority (MTA), which operates subway, bus and commuter rail service in New York City and its suburbs, pursued federal funding for congestion pricing implementation and complementary transit improvements. The City and MTA applied for funding under the U.S. Department of Transportation's Urban Partnership Program, which set aside about \$1 billion from a dozen highway and transit programs for applicants that satisfied criteria related to the "four ' $\mathrm{T}$ 's" of Tolling, Transit, Telecommuting, and Technology. In August, the City and MTA were awarded 
Table 1. Comparison of congestion pricing plans

\begin{tabular}{|c|c|c|}
\hline & $\begin{array}{l}\text { PlaNYC } \\
\text { (April 2007) }\end{array}$ & $\begin{array}{l}\text { Traffic Congestion Mitigation } \\
\text { Commission (Jan. 2008) }\end{array}$ \\
\hline Congestion charge & $\begin{array}{l}\$ 8 \text { daily fee for cars entering or } \\
\text { leaving the pricing zone. } \\
\$ 21 \text { daily fee for trucks except } \$ 7 \text { for } \\
\text { low-emission trucks. } \\
\$ 4 \text { for cars traveling solely within the } \\
\text { zone and } \$ 5.50 \text { for trucks. }\end{array}$ & $\begin{array}{l}\text { \$8 daily fee for cars entering the } \\
\text { pricing zone. } \\
\$ 21 \text { daily fee for trucks except } \$ 7 \\
\text { for low-emission trucks. } \\
\$ 1 \text { surcharge for cash payers (not } \\
\text { using E-ZPass). }\end{array}$ \\
\hline Northern boundary & 86 Street & 60 Street \\
\hline Hours & 6 a.m. to 6 p.m. & Same as PlaNYC \\
\hline Direction charged & In-bound, out-bound and intra-zonal & In-bound only. \\
\hline Free bypass & $\begin{array}{l}\text { Through trips using FDR Drive and } \\
\text { Route } 9 A \text { not charged provided they } \\
\text { do not enter surface streets }\end{array}$ & No free bypass for through trips \\
\hline Toll offsets & $\begin{array}{l}\text { For E-ZPass users, the value of all } \\
\text { tolls paid on bridges and tunnels in } \\
\text { New York City (including Hudson } \\
\text { River crossings) would be deducted } \\
\text { from the fee up to } \$ 8 \text { (cars) or } \$ 21 \\
\text { (trucks). No offset for cash payers. }\end{array}$ & Same as PlaNYC \\
\hline Exemptions & $\begin{array}{l}\text { The charge would apply to all } \\
\text { vehicles, except emergency } \\
\text { vehicles, transit vehicles, vehicles } \\
\text { with handicapped license plates, } \\
\text { medallion taxis, and neighborhood } \\
\text { car services (radio cars). }\end{array}$ & No recommendation \\
\hline Fee payment & $\begin{array}{l}\text { E-ZPass; drivers without E-Z Pass } \\
\text { would have their license plates } \\
\text { recorded by cameras and payments } \\
\text { could be made through the internet, } \\
\text { via telephone call center or at } \\
\text { participating retail outlets. }\end{array}$ & Same as PlaNYC \\
\hline Duration & Three-year pilot & No recommendation \\
\hline Revenues & $\begin{array}{l}\text { Dedicated to transportation } \\
\text { investments through SMART } \\
\text { Financing Authority }\end{array}$ & $\begin{array}{l}\text { Dedicated MTA "lock box" for } \\
\text { capital investment }\end{array}$ \\
\hline Other fees/taxes & None & $\begin{array}{l}\$ 1 \text { surcharge on taxi and livery } \\
\text { trips that start and/or end within } \\
\text { the zone during congestion pricing } \\
\text { hours. } \\
\text { Increased on-street parking meter } \\
\text { rates within the zone. } \\
\text { Elimination of the resident parking } \\
\text { tax abatement for off-street parking } \\
\text { garages and lots within the zone. }\end{array}$ \\
\hline
\end{tabular}

Sources: (City of New York, 2007, pp. 88-91, 95-96; Commission on Metropolitan Transportation Authority Financing, 2008, pp. 63-64) 
Figure 1. PlaNYC and Traffic Congestion Mitigation Commission (TCMC) pricing zones

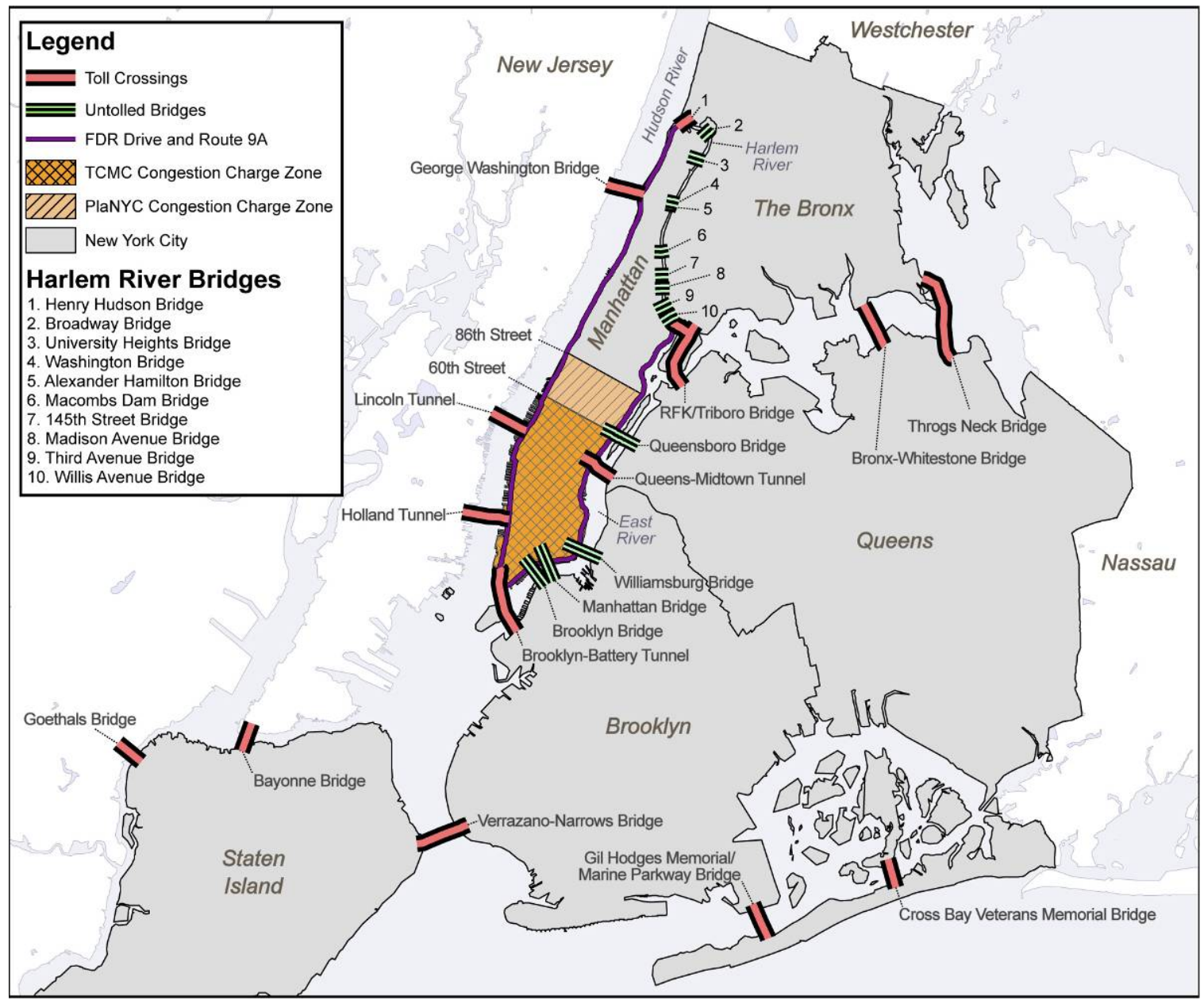

\$354 million in Urban Partnership funds, conditional on the Legislature granting pricing authority by early April 2008 and implementation of the congestion pricing system by March 31, 2009. Of five cities receiving Urban Partnership awards, New York was awarded the largest amount and had the most ambitious pricing proposal.

During the fall of 2007 and January 2008, the Traffic Congestion Mitigation Commission held 14 public hearings on the Mayor's plan and alternatives. With staff support from the New York City and State Departments of Transportation, the MTA and the Port Authority of New York and New Jersey, the Commission considered alternatives ranging from variations on the Mayor's plan to truck restrictions, telecommuting, taxi surcharges and license plate rationing.

In January, the Commission recommended a modified version of Bloomberg's original plan. The Commission plan removed neighborhoods on Manhattan's upper east and upper west sides from the pricing zone; eliminated the outbound fees so that the congestion pricing fee would be charged only to in-bound vehicles; and replaced the intra-zonal fee with taxes and surcharges on Manhattan parking garages and taxi trips. (See Table 1.) These modifications 
served to simplify operation of the scheme, sharply reduce the cost of building and operating the system, and focus pricing on trips that are responsible for the most severe congestion and have the best transit alternatives. These changes responded to public comment on the plan's complexity and fairness. Also in response to public comment, the Commission recommended a residential permit parking program to address potential parking impacts in areas just outside the pricing zone, a monitoring program, environmental review requirements and privacy protections (New York State Traffic Congestion Mitigation Commission, 2008, pp. 63-64).

The Commission recommendation was adopted by a vote of 13-2. Both "no" votes were cast by members appointed by the New York State Assembly Speaker, Sheldon Silver.

Analyses prepared for the Commission estimated that the plan would reduce vehicle miles traveled in the Manhattan core by $6.8 \%$. The plan would have reduced the amount of time that motorists spend in near-breakdown traffic conditions by over 30\% in the pricing zone and over $20 \%$ in adjacent areas. Net revenues were projected to be $\$ 491$ million annually (after operating expenses), all of which were to be devoted to transit enhancements through a dedicated MTA account known as a "lock box." The Commission plan called for expanded local and express bus and subway service to make transit a viable alternative for Manhattan-bound commuters and accommodate the influx of drivers switching modes (New York State Traffic Congestion Mitigation Commission, 2008).

The Commission’s plan was supported by Mayor Bloomberg, Governor David Paterson, a coalition of 135 civic, business, labor, environmental and advocacy groups and the editorial boards of all four major newspapers. It was endorsed by several suburban elected officials, including a county executive in suburban Long Island. The plan received surprisingly little opposition from other suburban officials or groups, many of whom supported the Mayor's sustainability goals. Within New York City, public and elected official support was strongest in Manhattan, the borough that is least auto-dependent and would benefit from reduced traffic and expanded bus service.

The most vocal opposition came from elected officials and civic groups in the four New York City boroughs outside Manhattan. Opposition was centered in eastern Queens and southern Brooklyn. These areas are more auto-dependent than neighborhoods closer to Manhattan and have the least rapid or convenient transit access to Manhattan jobs.

Some legislators from the inner areas of Queens, Brooklyn and the Bronx also had deep reservations about the congestion pricing plan, even though very few of their constituents would have been subject to congestion fees. These officials questioned whether funds would be spent effectively on transit service improvements. They also raised regional equity issues because New Jersey commuters would pay little or nothing in congestion fees (due to the toll offsets) while commuters from Queens, Brooklyn and the Bronx who use the free bridges would pay the full \$8 fee. Skepticism created by these concerns was amplified by outerborough residents' and elected officials' traditional resentments of Manhattan-based elites.

Public opinion polls in late March 2008 showed that New York City residents supported congestion pricing by a $67 \%$ to $27 \%$ margin, provided that the money would be used for mass transit improvements. However, a narrow majority of poll respondents doubted that pricing money would be used for mass transit. Without the provision for use of the funds, only $40 \%$ of New York City residents supported congestion pricing, about the same level as when the Mayor introduced the proposal (Quinnipiac University, 2008). 
After intensive City Hall lobbying, the City Council adopted a resolution in support of the Commission plan by a vote of 30-20. When the focus moved to Albany, the Republicancontrolled Senate was expected to adopt the plan if it came to a vote. The key obstacle was the Democratic-controlled Assembly. Democratic Assembly members from the outerboroughs were deeply skeptical of the plan. The Assembly Speaker, although publicly supportive, left the decision on whether to bring the bill to a vote to the Democratic conference. With strong opposition from most of its New York City members, Assembly Democrats blocked a vote as the deadline for federal funding approached. Without the required legislation, the federal funding deadline passed and the bill died. Shortly thereafter, the federal government reallocated the Urban Partnership funds conditionally awarded to New York City to Los Angeles and Chicago.

\section{ASSESSING THE OUTCOME}

In the immediate aftermath of the Legislature's disposition of congestion pricing, many people concluded simply that congestion pricing "failed" in New York City. Criticism for this outcome came from many directions, i.e., to opponents for having irresponsibly let pass the opportunity to reduce congestion and fund mass transit, and to proponents for not being more effective in enlisting legislative support (Confessore, 2008). But the perspective afforded by subsequent events and the passage of time leads to a more nuanced perspective on the outcome of the congestion pricing debate in New York City.

First, the debate over congestion pricing recast the public's understanding of transportation system needs in the city. As part of a 25-year sustainability plan, congestion pricing was embedded in goals related to climate change and the city's growth. It thus touched chords that transcended transportation needs and reached far beyond those traditionally focused on transportation issues. It was intuitively tied to problems experienced daily by millions of New Yorkers: jammed traffic, slow buses, crowded trains and dirty air. Moreover, the city's growth - visible in the new condominiums rising all over the city - profoundly shifted the lens through which these problems were viewed. No longer was the status quo a viable option; without action, the crowding and pollution would only grow worse, with dire consequences.

Congestion pricing in the context of sustainability, growth and quality of life thus coalesced a broad consensus across New York City that the city's future must be focused on sustainable transportation modes. Opponents as well as proponents of congestion pricing shared in this consensus, the two sides disagreeing only over whether congestion pricing should be used in service of these goals (See Keep NYC Congestion Tax Free, 2007). While congestion pricing was not implemented, the vision for a sustainable city and sustainable modes has endured. This consensus provides a critical foundation for the City's extensive program to promote walking, cycling and bus service. It also supports the City's efforts to view the city's streets as public spaces that contribute to quality of life (New York City Department of Transportation, 2008). In this way, the intensive year-long congestion pricing debate made a lasting positive contribution to improving mobility and environmental quality in New York City.

Why didn't this broad consensus for sustainable modes translate into approval of a congestion pricing proposal that had considerable support? The short answer is that a relatively small group of auto users believed that congestion pricing was against their best interests. As with many large highway construction projects in the 1970s and 1980s, the extensive approval process required for congestion pricing offered auto users an avenue to block action. The intensive interests of one group were thus able to overcome widespread public support. 
This may appear to be simply an often told tale of policy and politics. But to draw lessons for formulation of road pricing policy and strategy, it is valuable to examine in some detail why auto users opposed congestion pricing while others supported the proposal.

\subsection{Views of Supporters and Opponents of Congestion Pricing}

Whether support for PlaNYC's goals translated into support for congestion pricing depended on how each person evaluated the societal impacts of pricing on the city and region, and the individual-level impacts of pricing on transit riders and motorists. For most people, congestion pricing needed to make sense on both societal and individual levels to be seen as worthy of support. This fact sometimes led to surprising results, as when transit riders opposed pricing if they felt that drivers would be affected unfairly (Schaller, 2006, pp. 7, 11).

Table 2 summarizes the views on societal and individual-level impacts that tended to underpin views on congestion pricing. Supporters of congestion pricing generally emphasized the central societal benefits of reduced traffic, funding for transit and sustainable transport policy. Individual-level benefits were consistent with the societal benefits but were of secondary importance. In response to objections from auto users, supporters tended to see the $\$ 8$ fee as reasonably discouraging driving, particularly in light of increased transit service that would be funded by congestion pricing revenues.

Opposition to the charge was, by contrast, motivated primarily by individual-level impacts on drivers. Those most strongly opposed to congestion pricing felt that mass transit was not and would not become a viable alternative to driving. Moreover, they felt that the travel time savings from reduced congestion were questionable, and would not be worth the $\$ 8$ fee. Many of those most strongly opposed, whether private citizens or elected officials, had scant personal experience with the mass transit options of Manhattan auto commuters. Of those who did, their experience was often shaped by negative personal experiences such as having waited too long in the rain for a bus once too often. Issues of comfort, privacy and control - areas where even expanded mass transit services would have difficulty competing with the car - were often foremost.

In this context of the individual impacts on auto users, opponents saw congestion pricing as unfairly targeting the "working person" in the outerboroughs. Opponents viewed pricing as an attempt at social engineering by primarily Manhattan-based elites. They also objected to the fact that while East River bridge users would pay the full \$8 daily congestion fee, peak-hour commuters from New Jersey would have the congestion fee fully offset by Port Authority bridge and tunnel tolls. This issue of regional equity became a significant obstacle in legislative consideration of congestion pricing.

Opponents also disputed whether pricing would have the societal benefits claimed by pricing's supporters. Opponents pointed out that trucks, taxis and black cars contribute to Manhattan traffic congestion on a major scale. Opponents also doubted that revenues would reach the MTA, or if they did, that the MTA would use the funds to make the promised service improvements. If true, not even the individual-level benefits to transit riders would be realized and transit riders would suffer from even more crowded trains and buses. This skepticism was reinforced in March 2008 when, for budgetary reasons, the MTA canceled \$30 million in service improvements the agency had announced only three weeks earlier. 
Table 2. Summary of views on congestion pricing in New York City

\begin{tabular}{|c|c|c|c|}
\hline \multicolumn{2}{|c|}{ Assessment area } & $\begin{array}{l}\text { Views of congestion pricing } \\
\text { supporters }\end{array}$ & $\begin{array}{l}\text { Views of congestion pricing } \\
\text { opponents }\end{array}$ \\
\hline \multicolumn{2}{|c|}{ Societal impacts } & $\begin{array}{l}\text { Reduces traffic congestion } \\
\text { Funds better mass transit } \\
\text { Reduces air pollution } \\
\text { Furthers the goals of } \\
\text { sustainability, urban quality } \\
\text { of life } \\
\text { Reasonably discourages } \\
\text { often-unnecessary driving }\end{array}$ & $\begin{array}{l}\text { Congestion pricing targets } \\
\text { "working person" driving to } \\
\text { work, medical appointments, } \\
\text { etc. } \\
\text { Pricing represents social } \\
\text { engineering by Manhattan- } \\
\text { based elites } \\
\text { Little impact on Manhattan } \\
\text { traffic (trucks and taxis seen as } \\
\text { main cause of congestion in } \\
\text { central business district) } \\
\text { Revenue will be diverted from } \\
\text { the MTA } \\
\text { MTA cannot be trusted to use } \\
\text { new revenue for better service }\end{array}$ \\
\hline \multirow[t]{2}{*}{$\begin{array}{l}\text { Individual } \\
\text { level impacts } \\
\text { (evaluated } \\
\text { both for } \\
\text { oneself and } \\
\text { others) }\end{array}$} & $\begin{array}{l}\text { Impact on } \\
\text { transit riders }\end{array}$ & $\begin{array}{l}\text { Funds better transit } \\
\text { Transit improvements will } \\
\text { absorb increased ridership } \\
\text { from drivers switching to } \\
\text { transit }\end{array}$ & $\begin{array}{l}\text { Trains and buses will be more } \\
\text { crowded }\end{array}$ \\
\hline & $\begin{array}{l}\text { Impact on auto } \\
\text { users }\end{array}$ & $\begin{array}{l}\text { Drivers will have reasonable } \\
\text { transit alternative } \\
\text { Will benefit drivers by } \\
\text { reducing traffic congestion }\end{array}$ & $\begin{array}{l}\text { Transit is not and will not be } \\
\text { viable alternative to driving } \\
\text { Value of travel time savings } \\
\text { (if any) not worth the } \$ 8 \text { fee }\end{array}$ \\
\hline
\end{tabular}

Note: Main motivating arguments for proponents and opponents are in bold. 


\subsection{Approval process}

Unlike London, New York City needed to obtain authority under state law to implement congestion pricing. In the course of its consideration of congestion pricing, the State Legislature determined that a City Council resolution in support was also required before the Legislature could act. Thus, congestion pricing in New York City needed approval by three legislative bodies (the City Council and each house of the Legislature) as well as the Governor.

The City Council and State Assembly were controlled by Democrats while the State Senate was controlled by Republicans. Mayor Bloomberg, who ran for office as a Republican (becoming an Independent after winning re-election), had built constructive relationships with Senate Republicans and the City Council. Although approval from these bodies could not be taken for granted, the primary obstacle on the path to adoption was Assembly Democrats. This group was composed primarily of New York City members, most of whom represented the outerboroughs.

In the context of this approval process, outerborough Assembly Democrats were able to block action on congestion pricing legislation, with the stiffest opposition coming from members representing eastern Queens and southern Brooklyn. Thus, the Legislative outcome on congestion pricing grew directly from opposition motivated by the individual-level impacts on auto users.

Notably, even in areas of greatest resistance to congestion pricing, drivers who would have paid a congestion fee constitute a small proportion of the population. Only 5\% of workers in eastern Queens and southern Brooklyn commute by car into the Manhattan central business district, while several times that many commute to Manhattan jobs by transit (City of New York, 2007, p. 75).

Events a year later demonstrated the close relationship between individual-level impacts on auto and transit users and legislative support for road pricing. In late 2008, a panel appointed by Governor Paterson and chaired by former MTA Chairman Richard Ravitch proposed closing a $\$ 1.2$ billion MTA budget deficit by tolling the East River and Harlem River bridges, and levying a $0.34 \%$ payroll tax in the MTA region (Commission on Metropolitan Transportation Authority Financing, 2008). The proposal for bridge tolls was significantly different from the earlier congestion pricing proposals in several respects, most notably that charging would apply to vehicles crossing the Harlem River rather than crossing $60^{\text {th }}$ Street. Despite differences, both tolls and congestion pricing shared the central feature that anyone driving into the Manhattan core from the outerboroughs would pay a toll or fee.

In the course of Albany's discussion of the Ravitch panel recommendations, the Assembly speaker announced that he and his members would support bridge tolls and the payroll tax provided that tolls were reduced to $\$ 4$ for the round-trip (Peters, 2009). This compromise was backed by Ravitch and the Governor as well, though later blocked by the Senate.

The Assembly's willingness to support bridge tolls reflected a major change in the individual-level impacts of pricing in spring 2009 as compared with a year earlier. The MTA had announced over the winter that large fare increases and service cuts would be inevitable without new revenues. In fact, in late March the MTA Board adopted a 20\% to 30\% fare increase and service cuts that included elimination of 35 bus routes and two subway lines. These actions would have been implemented in early summer had the Legislature not acted. A year earlier the choice before legislators was certain pain for drivers in the form of the congestion fee versus seemingly less-than-certain congestion reduction and transit improvements. In 2009 the 
choice was between a more modest toll for drivers and certain pain for transit users. Equity concerns with tolls were mitigated by the compromise to reduce the toll to \$4 round-trip, equivalent to the cash subway fare at the time.

Ultimately, bridge tolls were blocked in the Senate. After more than 40 years in the minority, Senate Democrats gained a bare majority in the 2008 elections. In the face of solid Republican opposition to the Ravitch proposals, defection by even a single Democratic Senator was enough to block any aspect of the MTA funding rescue. With opposition from a handful of senators from the Bronx, Brooklyn and Queens, the bridge toll proposal was dropped. The Legislature adopted the payroll tax combined with a surcharge on taxi trips and increased fees or taxes for vehicle registrations, driver licenses and car rentals. The funds generated by these measures would close the MTA's operating deficit and fund two years of the capital program, deferring the issue of funding the remainder of the MTA's five-year capital program.

\section{LESSONS FOR ACCEPTANCE AND ADOPTION OF ROAD PRICING}

New York City's intensive consideration of congestion pricing offers a number of valuable lessons for others who seek to design and gain approval of pricing proposals. One set of lessons addresses strategies to build support for congestion pricing among elected officials, key constituencies and the general public. Another set of lessons involve designing pricing proposals that are most likely to gain approvals from state legislatures or other elected bodies.

\subsection{Building support of pricing proposals}

Congestion pricing gained support from key constituencies, members of the general public and some elected officials because of the vision and top-level leadership provided by City Hall coupled with an extensive public outreach and education campaign and strong advocacy from the civic community. Equally important, the proposal was part of a far-reaching plan that tied transportation to broad sustainability goals, the revised proposal was shaped by intensive public discussion, and the federal government would fund expanded transit services.

These key ingredients are not unique to congestion pricing in New York; indeed, New York City's experience mirrors that of other major cities whether they adopted cordon or area pricing schemes (e.g., London and Stockholm), rejected cordon pricing proposals after extensive consideration (e.g., Edinburgh, Scotland, Manchester, England and San Francisco); or approved other forms of road pricing such as high occupancy toll (HOT) lanes and new toll roads (Munnich and Loveland, 2005; Cain, 2005; K.T. Analytics, 2008a; K.T. Analytics, 2008b; Eliasson, 2008).

Key elements in the process of building support, reflected in the New York experience, are:

- Vision and top-level leadership. The sustainability vision of PlaNYC and leadership of Mayor Michael Bloomberg and his team were critical to bringing congestion pricing to center stage, building awareness of the congestion problem and gaining a consensus on the need for action.

- The broader plan involved transportation, climate change and land use goals. The public widely understood that congestion pricing could be successful only if it was part of a broader plan to expand and improve mass transit service and address issues raised by the city's growth. Congestion pricing's role as part of PlaNYC helped the public see the connections between pricing and larger sustainability goals, and 
showed that the City had a comprehensive approach to solving traffic and other problems that was not dependent solely on pricing.

- Public involvement shaped the final plan. Public involvement began with a panel that advised City Hall in PlaNYC development. Extensive public input to the Traffic Congestion Mitigation Commission, in particular a series of well-attended hearings held throughout the metropolitan area, led the Commission to make significant modifications to the Mayor's plan, addressing issues of simplicity, equity, cost, use of revenues and parking impacts. The Commission's consideration of a range of alternatives helped the public conclude that congestion pricing was necessary to achieve the Commission's goals. The process of public comment and modification of the proposal improved the plan and served to build greater support for the Commission's recommendations.

- Public education and outreach. An extensive program for outreach and public education helped the public, interested groups and elected officials understand PlaNYC as a whole and the benefits of congestion pricing. Outreach and education included presentations to numerous civic and community groups, direct mailing and fact sheets showing how residents of each Council and Legislative district would be affected by congestion charges and by transit improvements. As part of the public education campaign, proponents quickly responded to objections and issues raised by the public and opponents of congestion pricing, in order to head off misperceptions of the proposal.

- Leadership from civic, business, labor, environmental and advocacy groups. The City could not have garnered a high level of public support without the intensive efforts of numerous non-governmental groups. A coalition of these groups was formed by allies of City Hall to press the case in public discussions and with elected officials. The breadth and depth of support helped propel serious consideration of congestion pricing.

- Availability of federal funding. The \$354 million Urban Partnership grant and associated deadlines were important to building support for the proposal and accelerated the timeline for consideration and debate.

New York City's experience illustrates and underscores the importance of these elements in building a wide base of support and gaining approval through most albeit not all of the adoption process.

\subsection{Design of pricing proposals}

Just as there is much to learn from the progress made toward support for congestion pricing, there is also much to learn from its failure to go forward, particularly when the outcome in New York City is put in the context of the experience with road pricing proposals in other major cities.

One lesson is that congestion pricing can be thwarted by a relatively small group of people, particularly when it requires approval from several legislative bodies. While the City Council approved congestion pricing and the State Senate would likely have done so as well, opponents were able to block the proposal in the Assembly. And they did so despite their relatively small numbers; only 5\% of employed New York City residents would have paid the congestion fee as part of their daily commute (City of New York, 2007, p. 75). 
Cordon and area pricing proposals have run aground in other cities as well because of opposition from drivers who would have been charged a fee. In some cases, as with referenda in the Edinburgh and Manchester metropolitan areas, electoral majorities voted down cordon pricing proposals. In other cases, such as the proposed toll on Doyle Drive in San Francisco (connecting the Golden Gate Bridge to the downtown area), the relatively small number of affected motorists were able to prevent approval in the California Legislature.

The out-sized power of negatively affected groups to block a proposal is not new to road pricing. Because neighborhood residents have been able to stop large-scale highway, transit and airport projects, major transportation projects since the 1970s have been subject to a "do no harm" constraint. Proponents of such projects have had plan them to "be sited, designed and mitigated so as to leave no victims in their wake.” (Altshuler and Luberoff, 2003, p. 228) Drivers in New York City who would have had to pay as much as \$2,000 annually in congestion fees showed a similar power to prevent adoption.

Most successful pricing projects in the United States have offered drivers a non-priced roadway alternative. HOT lanes, for example, provide a choice of priced lanes and unpriced general purpose lanes. The same is true for construction of new toll roads or of new priced lanes added to existing highways. In both cases, motorists continue to enjoy the option of using existing untolled roads, and thus have little reason to oppose these forms of road pricing. Although gaining approval of HOT lanes and new construction of tolled lanes is by no means a simple task, they have become the most widely implemented form of road pricing in the United States (DKS Associates, 2009, pp. 2-3).

London and Stockholm are notable for having implemented congestion pricing schemes that require all drivers entering the downtown area to pay a congestion fee (or tax, as in Stockholm). The difference between these cities and New York, Manchester and Edinburgh was that approval processes and political circumstances worked in favor of adoption. In London, the Mayor had the authority to implement congestion pricing without any legislative approvals. The politics worked in favor of the proposal, since the auto lobby was largely aligned with the Mayor's political opponents. Stockholm's system required legislative authorization, which it obtained through a fortuitous set of political circumstances in which the Green Party made congestion pricing a condition of becoming part of a governing coalition. After a seven month trial demonstrated the benefits of the system, it was made permanent after narrowly passing in a public referendum (Eliasson, 2008, pp. 395-96).

While it is entirely possible that favorable political circumstances can lead to congestion pricing's adoption in the United States, it seems likely to be the exception rather than the rule. Few cities have the legal authority to impose congestion fees without state legislative approval, and the type of coalition politics that occurred in Sweden would be highly unusual in the United States.

This observation leads to a second lesson from the New York City experience. Given the power of small interest groups to prevent adoption of cordon and area pricing proposals, schemes that require all drivers to pay will need to convince drivers that they will benefit from the scheme. Otherwise, they are likely to prevail in opposing the proposal. But the case for driver benefits is not an easy one to make. Drivers are unlikely to feel that the value of congestion reduction is worth the fee. Their view is by no means irrational since pricing usually "make(s) travelers worse off before the usage of revenues is accounted for.” (De Palma, Lindsey and Niskanen, 2006, p. 161) Where revenues are used to benefit others (e.g., transit riders), society 
may be better off with congestion pricing, but individual drivers are worse off and are thus motivated to block adoption.

Moreover, proposals in which revenues would be devoted to road improvements still need to demonstrate why a select group of drivers should pay while others do not. A targeted fee or toll is most readily justified where a facility such as a bridge or tunnel depends on the revenues to pay off construction bonds. It is more difficult to justify a targeted fee or toll for a pricing zone unless the revenues are used to uniquely benefit drivers entering the pricing zone. For this reason, revenue for road improvements is generally raised through broad-based taxes such as the gas tax which apply to all motorists.

These lessons from the New York City experience, supported by experience elsewhere, suggests that it will be very difficult to obtain approval of congestion pricing in U.S. cities. Does this experience suggest that there might be a more viable policy approach for wide implementation of road pricing that involves area-wide charging?

There are in fact several examples of pricing schemes that require all motorists to pay a fee or tax, yet gained their support. One example is the Dutch mileage-based system that is planned for implementation starting in 2011 for trucks and 2012 for cars. The Dutch fee will replace existing road taxes and a $40 \%$ sales tax on new cars. High-mileage drivers will pay more under the mileage charge than they do currently, but many drivers are expected to pay less and total revenues will be unchanged. Overall, the plan is seen as creating a fairer and more equitable system for raising revenue. (House of Commons Transport Committee, 2009, p. 53)

Another example is curbside pricing of truck delivery zones throughout the Manhattan business district. This pricing scheme gained support among truckers and delivery companies because they saw the benefits of better parking space availability and reduced congestion from double-parked trucks as being worth the parking fees. Similarly, peak-rate parking pilots in neighborhood retail corridors in New York City have recently gained support from local merchants who believe that the program will improve availability of metered parking for local shoppers.

It is widely viewed that mileage-based taxes need to replace the gas tax as the primary source of transportation funding over the next several decades (National Surface Transportation Policy and Revenue Study Commission, 2008, pp. 52-53; National Surface Transportation Infrastructure Financing Commission, 2009, pp. 9-10). To gain public support, mileage-based taxes must be viewed as fair and as benefitting drivers. Following the Dutch example, a revenue-neutral conversion from gas taxes to a mileage-based tax can reduce the tax paid by many and potentially most motorists. A tax based on mileage driven and the amount of gasoline burned can be viewed by the public as enhancing equity, particularly with increased use of electric vehicles. Drivers can also be offered features built on the in-vehicle devices necessary to collect mileage-based charges, such as "pay as you drive” insurance, vehicle location services, real-time traffic alerts and so forth. Initial implementation of a VMT tax in the U.S. might focus on groups that currently pay substantial road use fees, such as truckers who pay state-imposed mileage-weight fees. Benefits in this case may include elimination of cumbersome paperwork and leveling the playing field between those who pay and those who currently evade the tax.

Implementation of mileage-based pricing would need to be preceded by extensive trials and demonstration projects and would likely occur in phases (National Surface Transportation Infrastructure Financing Commission, 2009, p. 154). To maximize public acceptance, demonstrations could start with a voluntary opt-in phase, thus showing system benefits before any drivers are required to switch to a mileage-based system. Significant reductions in traffic 
congestion from only small changes in daily travel, shown to occur in pilots in Portland and the Puget Sound areas, (Puget Sound Regional Council, 2008; Whitty, 2007) can be demonstrated. A phased implementation approach can thus demonstrate the system's fairness and benefits to drivers - as well as addressing privacy, reliability and cost issues - all before any motorist is required to pay a mileage-based tax.

Ultimately, mileage-based pricing can include a congestion pricing overlay that focuses on the places and times of greatest congestion, more precisely targeting congestion reduction than cordon or area congestion pricing is able to do. A congestion pricing overlay can be charged for all roads in targeted areas, overcoming the very significant public concerns with diversion from congested highways to local roads (Petrella, Biernbaum and Lappin, 2007, p. 15). Because the charge can be specific to individual road segments, mileage-based pricing can directly link motorists' payments to improvements to roads and transit services. Such linkage can be critical to building public support for pricing and thus for addressing transportation finance needs. The ability to transparently link benefits, revenues and tax rates is likely to be mileage-based pricing's most significant long-term contribution to the transportation system.

New York City's experience with its congestion pricing proposal, like that of other cities that have considered but not adopted road pricing, has produced important benefits. The debate over congestion pricing and larger discussion of PlaNYC has been critical to developing support for a broader transportation agenda that emphasizes non-auto modes, sustainability and quality of life. Both locally and nationally, New York City's experience also helps identify keys to gaining public acceptance of road pricing to meet critical funding, transportation and environmental objectives. 


\section{References}

Altshuler, A. and Luberoff, D (2003) Mega-Projects; The Changing Politics of Urban Public Investment, Brookings Institution Press, Washington DC.

Cain, A. (2005) 'Achieving Majority Public Support for Urban Road Pricing: Preserving the Driver’s Right to Choose', Transportation Research Record, No. 1932, pp. 119-128.

City of New York (2007) 'PlaNYC: A Greener, Greater New York’, April 2007.

Commission on Metropolitan Transportation Authority Financing (Ravitch Commission) (2008) 'Report to Governor David A. Paterson', December 2008.

Confessore, N. (2008) '\$8 Traffic Fee for Manhattan Gets Nowhere’, New York Times, April 8, 2008.

De Palma, A., Lindsey, R. and Niskanen, E. (2006) 'Policy insights from the urban road pricing case studies’, Transport Policy, 13 (2), pp. 149-161.

DKS Associates (2009) 'A Domestic Scan of Congestion Pricing and Managed Lanes’, Federal Highway Administration, April 2009.

Eliasson, J. (2008) 'Lessons from the Stockholm Congestion Charging Trial', Transport Policy, 15 (6), pp. 395-404.

House of Commons Transport Committee (2009) 'Taxes and Charges on Road Users: Sixth Report of Session 2008-09', July 2009.

K.T. Analytics (2008a) 'Lessons Learned From International Experience in Congestion Pricing', Federal Highway Administration, August 2008.

K.T. Analytics (2008b) 'Value Pricing Pilot Program: Lessons Learned’, Federal Highway Administration, August 2008.

Keep NYC Congestion Tax Free (2007) 'Alternative Approaches to Traffic Congestion Mitigation in the Manhattan Central Business District’, October 2007.

Michaels Opinion Research (2006) 'New Yorkers on Traffic and Transportation', Tri-State Transportation Campaign, May 2006.

Munnich, L. and Loveland, J. D. (2005) 'Value Pricing and Public Outreach: Minnesota’s Lessons Learned’, Transportation Research Record, No. 1932, pp. 164-168.

National Surface Transportation Infrastructure Financing Commission (2009) 'Paying Our Way: A New Framework for Transportation Finance', February 2009. 
National Surface Transportation Policy and Revenue Study Commission (2008) 'Transportation for Tomorrow: Report of the National Surface Transportation Policy and Revenue Study Commission', January 2008.

New York City Department of Transportation (2008)‘Sustainable Streets Strategic Plan’, May 2008.

New York State Traffic Congestion Mitigation Commission (2008) 'Report to the Traffic Congestion Mitigation Commission \& Recommended Implementation Plan’, January 31, 2008.

Partnership for New York City (2006) 'Growth or Gridlock? The Economic Case for Traffic Relief and Transit Improvement for a Greater New York’, December 2006.

Peters, J. (2009) 'Silver Proposes Tolls on East and Harlem River Bridges', New York Times, February 26, 2009.

Petrella, M., Biernbaum, L. and Lappin, J. (2007) 'Exploring a New Congestion Pricing Concept: Focus Group Findings from Northern Virginia and Philadelphia’, Volpe National Transportation Systems Center, prepared for Federal Highway Administration, December 2007.

Puget Sound Regional Council (2008) ‘Traffic Choices Study’, April 2008.

Quinnipiac University Polling Institute (2008) 'Voters Back Congestion Pricing, If Funds Go To Transit', March 28, 2008.

Schaller Consulting (2006) 'Necessity or Choice? Why People Drive in Manhattan’, February 2006.

Schaller, B. (2006) 'Battling Traffic: What New Yorkers Think about Road Pricing', Center for Rethinking Development, Manhattan Institute, December 2006.

Whitty, J. (2007) ‘Oregon’s Mileage Fee Concept and Road User Fee Pilot Program Final Report', Oregon Department of Transportation, November 2007.

Zupan, J. and Perrotta, A. (2003) 'An Exploration of Motor Vehicle Congestion Pricing in New York’, Regional Plan Association, November 2003. 